\title{
UPAYA MENGEMBANGKAN KOGNITIF DALAM MENCOCOKKAN BILANGAN DENGAN LAMBANG BILANGAN MELALUI MODEL MAKE A MATCH DI KELOMPOK B TK. AISYIYAH 6 BANJARMASIN
}

\author{
Oleh: Milliannoor \\ (Mahasiswa S1 PG PAUD Universitas lambung Mangkurat)
}

\begin{abstract}
Abstrak
Permasalahan dalam penelitian ini adalah dalam mengenal bilangan masih lemah dan perlu ditingkatkan hal ini dapat dilihat pada kenyataan dilapangan saat guru TK. Aisyiyah 6 memberikan materi tentang mengenal bilangan, dari 18 orang anak hanya 6 orang berkembang sesuai dengan harapan sedangkan 12 lainnya masih dikategorikan mulai berkembang dan itu artinya 35\% yang berhasil. Hal ini disebabkan antara lain kurangnya keterlibatan aktivitas siswa dalam pembelajaran mengenal lambang bilangan. Oleh sebab itu perlu dilakukan perbaikan pembelajaran dengan menggunakan model Make a Match. Tujuan dari penelitian ini adalah untuk mengetahui aktivitas guru, aktivitas anak, dan hasil pengembangan kognitif anak.

Jenis Penelitian yang digunakan adalah penelitian tindakan kelas. Tindakan dilaksanakan dalam dua siklus, dengan setting penelitian adalah kelompok B TK. Aisyiyah 6 Banjarmasin, dengan jumlah anak 18 orang yang terdiri dari 10 anak laki-laki dan 8 orang anak perempuan. Jenis data dan penelitian ini adalah data kuantitatif dan kualitatif. Data kuantitatif diperoleh melalui teknik pengukuran dengan evaluasi pada anak. Sedangkan data kualitatif diperoleh dari hasil observasi aktivitas guru dan siswa. Analisis data secara naratif dan teknik persentase berdasarkan skala persentase dan indikator ketuntasan pengembangan yang ditentukan.

Hasil penelitian menunjukkan bahwa aktivitas guru, aktivitas siswa, dan hasil belajar pengembangan kognitif anak kelompok B TK Aisyiyah 6 Banjarmasin mengalami perbaikan. Hal ini terlihat dari hasil observasi aktivitas guru yaitu mendapat katagori baik pada pertemuan 1, dan pada pertemuan 2 juga mendapatkan katagori baik, sedangkan pada siklus II mengalami perbaikan mendapatkan katagori sangat baik, sedangkan observasi aktivitas anak yaitu 62,5\% katagori aktif pada pertemuan 1 siklus I, dan 77,32\% katagori aktif pada pertemuan 2, meningkat menjadi $88,89 \%$ katagori sangat aktif pada siklus II begitu juga dengan hasil pengembangan anak yaitu $27,78 \%$ di bawah indikator ketuntasan pengembangan, kemudian meningkat pada siklus II menjadi $100 \%$ di atas indikator ketuntasan yang telah ditetapkan.

Berdasarkan hasil temuan penelitian ini bahwa penggunaan model make a match dapat meningkatkan hasil pengembangan kognitif dalam mencocokkan bilangan dengan lambang bilangan di kelompok B TK. Aisyiyah 6 Banjarmasin, disarankan agar guru-guru di tamak kanakkanak dapat menggunakan model ini dalam melaksanakan kegiatan pengembangan kognitif sebagai upaya dalam menciptakan perbaikan dan meningkatkan pemahaman anak, aktivitas anak serta meningkatkan mutu kualitas pembelajaran disekolah masing-masing.
\end{abstract}

Kata-kata Kunci: Pengembangan Kognitif, Mencocokkan Bilangan, Lambang Bilangan, Model Make A Match. 


\section{A. Pendahuluan}

Pendidikan prasekolah berkembang tidak hanya di negara maju, tetapi juga di negaranegara berkembang. Saat ini banyak ditemukan pelayanan pendidikan prasekolah, baik yang diselenggarakan oleh pemerintah maupun swasta. Berbagai alternatif program pendidikan untuk anak prasekolah, baik yang diselenggarakan di sekolah maupun di luar sekolah, banyak ditawarkan, antara lain Taman Kanak-Kanak, Tempat Penitipan Anak, dan Program Bina Keluarga dan Balita, Play group, Taman Bermain sejahtera dan lain-lain.

Pembelajaran di Taman Kanak-Kanak lebih banyak difokuskan pada bidang dasar (basic) , yaitu membaca, menulis, dan berhitung yang dikenal dengan "Three Rs", yaitu Reading, Writing, dan Aritmathic. Istilah "Back to Basic" yang sering didengar tidak lain merupakan istilah "Tiga R" tersebut, yang artinya mengembalikan nfokus pembelajaran Taman Kanak-Kanak atau Sekolah Dasar kelas awal kearah kegaitan membaca, menulis, dan berhitung. Di Indonesia "Tiga R" dikenal dengan istilah "Calistung”, yaitu membaca, menulis, dan berhitung.

Kegiatan pembelajaran di Taman KanakKanak tidak sekedar untuk mengembangkan "Tiga R", tetapi untuk mengembangkan berbagai aspek perkembangan anak, terutama aspek kognitif. Disamping itu matematika juga berfungsi untuk mengembangkan kecerdasan anak, khususnya kecerdasan yang oleh Gardner (Rahayu, 1995:1).

Matematika atau berhitung merupakan hal akrab dalam kehidupan manusia. Setiap hari, bahkan setiap menit orang menggunakan matematika. Belanja, menghitung benda, waktu, tempat, jarak, dan kecepatan merupakan fungsi matematis. Memahami grafik, tabel, berat, dan volume juga merupakan fungsi matematika. Dengan kata lain matematika sangat penting bagi kehidupan kita.

Pada proses perkembangan pada anak usia dini, pada mulanya anak tidak tahu bilangan, angka dan operasi bilangan matematis. Secara bertahap sesuai perkembnagan mentalnya anak belajar membilang, mengenal angka dan berhitung. Anak belajar menghubungkan objek nyata dengan simbol-simbol matematis. Sebagai contoh, sebuah jeruk diberi simbol angka "1" dan dua buah jeruk diberi simbol dengan angka "2". Demikian pula simbol “+” yang berarti dijumlah dan simbol “_“ yang berarti dikurangi.

Salah satu kemampuan anak yang sedang berkembang usia TK adalah kemampuan kognitif. Kemampuan kognitif diperlukan oleh anak dalam rangka mengembangkan pengetahuan tentang apa yang dilihat, dengan rasa, raba, ataupun mencium melalui panca indera yang dimilikinya. Di Taman Kanak- 
Kanak dan lembaga pendidikan sejenisya, pengembangan kognitif dikenal dengan istilah pengembangan daya pikir.

Satu-satunya cara yang efektif untuk memperluas dan memperkaya perkembangan kognitif anak adalah menawarkan kaesempatan bermain dalam lingkungan yang tidak menakutkan dan mengetahui dalam pengembangan permainan anak. Melalui obsevasi, guru /pendidik dapat mengenali perlu atau tidaknya intervensi (ikut campur) pendidik untuk meningkatkan kemampuan berpikir anak. Bagaimana anak berinteraksi dengan bahan-bahan, menentukan apakah guru harus menggunakan respon langsung atau tidak langsung. Contoh, jika suatu kativitas mulai menjadi pengulangan pada anak-anak pendidik perlu menggunakan interaksi (hubungan) langsung agar kegiatan tersebut tidak membuat anak bosan. (Aisyah, dkk:2009)

Guru taman kanak-kanak perlu menguasai konsep-konsep matematika sederhana yang sesuai untu taman kanak-kanak. Berbagai notasi matematis sederhana dan cara pengenalannya perlu dipahami secara mendalam, agar dapat melatih anak berhitung dan menggunakan fungsi-fungsi matematis lainnya. Menurut Piaget, pengenalan matematika sebaiknya dilakukan melalui penggunaan benda-benda konkrit dan pembiasaan penggunaan matematika agar anak dapat memahami matematika, seperti berhitung, bilangan, dan operasi bilangan. Sebagai contoh, mengingatkan anak tentang tanggal hari ini dan menuliskannya dipapan tulis akan melatih anak mangenal bilangan.

Kemampuan anak kelompok B TK. Aisyiyah 6 dalam mengenal bilangan masih lemah dan perlu ditingkatkan hal ini dapat dilihat pada kenyataan dilapangan saat guru TK. Aisyiyah 6 memberikan materi tentang mengenal bilangan, dari 18 orang anak hanya 6 orang berkembang sesuai dengan harapan sedangkan 12 lainnya masih dikategorikan mulai berkembang dan itu artinya $35 \%$ yang berhasil. Hal ini disebabkan antara lain masih kurangnya kemampuan dan peran dari orang tua serta guru dalam peningkatan kemampuan anak dalam mengenal bilangan, jika keadaan ini dibiarkan, maka kemampuan anak dalam mengenal bilangan tidak akan meningkat, untuk itu perlu dicarikan jalan keluarnya.

Peningkatan kemampuan mengenal bilangan pada anak usia prasekolah sangat penting arena kemampuan ini merupakan kemampuan matematika awal anak, yang nantinya berguna dalam kehidupan sehari-hari anak, mengingat masih banyak ditemui anak didik yang masih rendah kemampuan dalam mengenal bilangan, hal ini perlu segera diatasi dan diupayakan jalan keluarnya, karena jika tidak maka kemampuan kognitif anak dalam hal mengenal bilangan akan tidak berkembang secara maksimal. Salah satu cara yang dapat ditempuh dalam meningkatkan 
kemampuan mengenal bilangan antara lain melalui Permainan Kartu angka meningkatkan partisipasi dan keaktifan anak dalam kelas, guru menerapkan metode pembelajaran yang sesuai.

Model pembelajaran kooperatif model Make a Match merupakan tipe pembelajaran untuk mengatasi masalah tersebut. Model make a match adalah permainan yang menarik dalam mecari pasangan kartu permainan.

\section{B. Kajian Teori}

\section{Karekteristik Anak Usia 3-5 tahun}

Ada beragam pendapat tentang batasan anak usia dini, antara lain disampaikan oleh NAEYC (National Association for The Education of Young Children), yang mengatakan anak usia dini adalaha anak yang berada pada rentang usia 0-6 tahun, yang tercakup dalam program pendidikan di taman penitipan anak, penitipan anak pada keluarga, pendidikan prasekolah baik swasta maupun negeri, TK dan SD, sedangkan UndangUndang Republik Indonesia nomor 20 tahun 2003 tentang system Pendidikan Nasional pada pasal 1 ayat 14 menyatakan bahwa : Pendidikan anak usia dini adalah suatu upaya pembinaan yang ditujukan kepada anak sejak lahir sampai dengan usia enam tahun yang dilakukan melalui pemberian rangsangan pendidikan untuk membantu pertumbuhan dan perkembangan jasmani dan rohani agar anak memiliki kesiapan dalam memasuki pendidikan lebih lanjut. Jadi anak usia dini adalah anak yang berusia 0-6 tahun.

Suatu hal yang cukup menonjol pada masa 35 tahun adalah munculnya berbagai bentuk kreatifitas dalam bermain sehingga masa ini dinamakan periode sebagai masa kreatif diyakini bahwa kreatifitas yang ditujukan anak pada masa ini merupakan kreatifitas yang original dengan frekuensi kemunculannya yang seolah tanpa terkendali dibandingkan dengan masa-masa lain dalam kehidupan seorang anak setelah masa ini berlaplu. (Sudjiono,2008).

Dapat dikatakan usia 3-5 tahun adalah usia emas (golden age) selain ditandai dengan munculnya masa peka terhadap sejumlah aspek perkembangan masa ini ditandai dengan berbagai bentuk kreatifitas dalam bermain yang muncul dari daya imajinasi anak. pemberian stimulasi yang sesuai dengan perkembangan anak akan menajdikan mereka lebih matang baik secara fisik maupun psikis. (Sudjiono, 2008).

Pendidikan anak usia dini merupakan proses interaksi antara pendidik (orang tua, pengasuh, dan guru) dengan anak usia dini secara terencana untuk mencapai tujuan. Dalam proses interaksi pendidik harus memahami segala spek pertumbuhan dan perkembangan anak usia dini yang dihadapinya. Karena dengan memperhatikan pemahaman pertumbuhan dan perkembangan 
anak usia dini, pendidik dapat menyesuaikan segala bentuk ucapan, sikap dan tindakan pembelajaran sesuai dengan kebutuhan pertumbuhan serta perkembangan anak usia dini. Dalam kesempatan ini pendidik sekaligus mengarahkan anak bisa membangun kecerdasan moral yang akan menjadi otot kuat yang diperlukan untuk melawan tekanan buruk dan membekali anak untuk mempunyai kemampuan bertindak benar tanpa bantuan orang lain.

\section{Teori Dasar Perkembangan Kognitif}

Mengenai perkembangan kognitif, Piaget berpendapat bahwa anak pada rentang usia ini, masuk dalam perkembangan berpikir Praoperasional konkret. Pada saat ini sifat egosentris pada anak semakin nyata. Anak mulai berpikir prespektif yang berbeda dengan orang lain yang berada disekitarnya. Orang tua sering menganggap priode ini sebagai masa sulit karena anak menjadi susah diatur, biasanya dikenal dengan istilah nakal atau bendel, suka membantah dan banyak bertanya. Menurut sumber lain ciri-ciri pada usia ini, yaitu anak mengembangkan keterampilan berbahasa dan menggambar, namun egois dan tidak bisa mengertoi penelaran abstrak atau logika. (Sudjiono, 2008)

Setiap anak akan mengalami masa-masa pertumbuhan dan perkembangan pada berbagai dimensi. Perkembangan setiap anak tidaklah sama karena setiap individu memiliki tempo dan perkembangan yang berbeda, apabila pada anak diberikan stimulasi adekatif secara insentif dari lingkungannya maka anak mampu menjalani tugas perkembangannya dengan baik, sekalipun terdapat bahaya potensial yang selalu perlu diwaspadai. Pada rentang usia 3-5 tahun anak mulai memasuki usia prasekolah atau taman kanak-kanak , apabila orang tua memberikan respon yang kurang baik terhadap tingkah laku anak maka anak dikhawatirkan tidak akan dapat mengembangkan potensinya secara optimal.

Dewey mengatakan bahawa pendidikan harus memberikan kesempatan pada setiap anak untuk dapat melakukan sesuatu, baik secara individu maupun kelompok sehingga anak akan memperolah pengalaman dan pengetahuan. Sekolah harus dijadikan laboratorium bekerja bagi anak. (Sudjiono, 2008:2.7)

Sedangkan menurut Gessel dan Amatruda mengemukakan bahwa anak usia 3-4 tahun mulai berbicara secara jelas dan berarti. Kalimat-kalimat yang diucapkan akan semakin baik. Ia menamakan masa ini sebagai masa perkembangan fungsi bicara. Pada usia 4-5 tahun, yaitu masa belajar matematika sederhana, misalnya menyebut bilangan, menghitung urutan bilangan, dan penguasaan jumlah kecil dari benda-benda. (Sudjiono,2008:2.8). 


\section{Pengertian Kognitif}

Kognitif adalah pengertian yang luas mengenai cara berpikir dan mengamati, jadi merupakan tingkah laku yang mengakibatkan seseorang memperoleh pengetahuan yang dibutuhkan, untuk memperoleh pengetahuan atau menggunakan pengetahuan yang diperolehnya. Kognitif adalah proses yang terjadi secara internal didalam pusat susunan syaraf pada waktu manusia berpikir. (Gagne, 1996)

Kemampuan kognitif ini berkembang secara bertahap sejalan dengan perkembangan fisik dan syaraf-sayaraf yang berada dipusat susunan syaraf. Jean Piaget seorang ahli biologi dan psikologi kaebangsaan Swiss, merumuskan teori fase-fase perkembangan kognitif. Teori ini dibangun berdasarkan dua sudut pandang, yaitu aliran (structural) dan konstruksif. Aliran (structural) yang mewarnai teori Piaget dapat dilihat dari pandangannya tentang intelegensi atau kecerdasan seorang anak manusia berkembang melalui serangkaian tahapan perkembangan yang ditandai oleh perkembangan structural kualits kognitif, aliran konstruksif terlihat dari pandangan Piaget yang menyatakan bahwa seorang anak manusia membangun kemampuan kognitif malalui interaksi dengan dunia sekitarnya. Piaget menyatakan bahwa seorng anak bagai ilmuwan cilik atau peneliti kecil yang selalu sibuk membangun teorinya tetang dunia sekitarnya melalui interaksi dengan lingkungan dimana anak berada. Hasil interaksi ini adalah terbentuknya skem atau struktur kognitif bangunan pengetahuan yang dimulai terbentuknya struktur secara logis, kemudian berkembang menjadi suatu kesimpulan umum (generalisasi).

\section{Permainan Matematika di Taman Kanak-Kanak}

Belajar matematika terjadi secara alami seperti pada saat anak bermain. Anak usia dini menemukan, menguji serta menerapkan konsep metematika secara alami hampir setiap hari kegiatan-kegiatan yang mereka lakukan. Kegiatan belajar matematika secara sederhana terjadi dalam kehidupan seharihari.

Konsep matematika modern sekarang ini tidak lagi hanya pada konsep bilangan, tetapi lebih berkaitan dengan konsep-konsep abstrak dimana suatu kebenaran matematika dikembangkan berdasarkan alasan logis dengan menggunakan pembuktian dedukatif. Matematika sebagai i,mu tentang struktur dan hubungan-hubungan yang memerlukan simbol-simbol untuk membantu memanipulasi aturan-aturan melalui operasi yng dilakukan. (Sudjiono, 2008:11.4)

Secara umum permainan matematika di Taman Kanak-kanak bertujuan agar anak dapat mengetahui dasar-dasar pembelajaran berhitung dalam suasana yang menarik, 
aman, nyaman dan menyenangkan, sehingga diharapkan nantinya anak akan memiliki kesiapan dalam mwngikuti pelajaran matematika yang sesungguhnya disekolah dasar. (Sudjono, 2008:11.4)

Manfaat permainan matematika pada anak usia dini adalah membelajarkan anak pada konsep matematika yang benar menarik dan menyenangkan, membantu anak belajar matematika secara alami melalui kegiatan bermain. Peran guru dalam mengembangkan kegiatan belajar permainan matematika membangun rasa keingintahuan anak seacra alami tentang bentuk, ukuran, jumlah, dan konsep-konsep dasar lain dalam matematika.

Bagi anak yang belum memahami bilangan, menghitung bisa dari mana saja, kearah mana saja, boleh diulang, dan tidak harus urut. Benda yang oleh orang dewasa dihitung tiga, bisa menjadi lima bagi anak yang belum memahami bilangan. Jadi, meskipun anak dapat menghitung "satu", "dua", "tiga", dan seterusnya, tidak berarti bahwa anak memahami bilangan.

Menurut Piaget anak TK berada pada fase perkembangan pra operasional menuju ke konkret. Anak pada fase tersebut belajar terbaik dari benda nyata. Oleh karena itu, orang tua dan guru dapat mengenalkan bilangan kepada anak dengan menggunakan benda-benda. Berbagai benda yang ada di sekitar ita dapat digunakan untuk melatih anak berhitung, berpikir logis dan matematis. Beberapa contoh melatih anak mengenal bilangan :

1. Bercerita dengan permainan kartu angka

2. Permainan Angka

3. Permainan berhitung

4. Menyanyi angka

5. Teka-teki angka dan jumlah

\section{Pengertian Model Pembelajaran Make A Match}

Model pembelajaran Make a Match artinya model pembelajaran mencari pasangan. Setiap anak mendapat sebuah kartu (soal atau jawaban), lalu secepatnya mencari pasangan yang sesuai dengan kartu yang ia pegang. Suasana pembelajaran dalam model pembelajaran Make a Match akan riuh, tetapi sangat asyik dan menyenangkan. (Muhammad, 2009:Online)

Tehnik pembelajaran Make a Match atau mencari pasangan dikembangkan oleh Lorna Curran (1994). Salah satu keunggulan teknik ini adalah anak mencari pasangan sambil belajar mengenal suatu konsep atau topic dalam suasana yang menyenangkan. Langkah-langkah dalam penerapan model pembelajaran Make a Match yaitu:

a. Guru menjelaskan materi dan memperagakan materi

b. Guru menyiapkan beberapa kartu yang berisi beberapa konsep atau topik yang 
cocok untuk sesi review, satu bagian kartu soal dan bagian lainnya kartu jawaban.

c. Guru membagikan kartu soal dan kartu jawaban yang berbeda pada tiap kelompok/ anak.

d. Guru membimbing dan member tugas pada anak untuk menyiapkan jawaban dari kartu yang dipegangnya.

e. Guru meminta setiap anak mencari pasangan kartu yang cocok dengan kartunya.

f. Guru member point pada setiap anak/kelompok yang dapat mencocokkan kartunya sebelum batas waktu.

g. Setelah satu babak, kartu dikocok lagi agar tiap anak mendapatkan kartu yang berbeda dari sebelumnya, demikian seterusnya.

h. Melakukan permainan ulang sampai kartu terbagi pada anak/ kelompok.

i. Guru bersama-sama dengan anak membuat kesimpulan terhadap materi pembelajaran.

j. Guru mengadakan evaluasi melalui LKS.

\section{Keunggulan dan Kelemahan Model Pembelajaran Make A Match}

Model Make A Match mempunyai keunggulan dan kelemahan. Keunggulannya adalah:

a. Suasana kegembiraan akan tumbuh dalam proses pembelajaran

b. Kerjasama antar anak terwujud dengan dinamis

c. Munculnya dinamika gotong royong yang merata diseluruh anak
Sedangkan kelemahannya adalah:

a. Diperlukan bimbingan dari guru untuk melakukan kegiatan

b. Waktu yang tersedia perlu dibatasi jangan sampai anak terlalu banyak bermain-main dalam proses pembelajaran dan

c. Guru persiapan bahan dan alat yang memadai.

\section{Metodologi penelitian}

\section{Pendekatan Penelitian}

Jenis penelitian yang digunakan adalah penelitian tindakan kelas (Classroom Action Research) yaitu "suatu bentuk kajian yang bersifat reflektif oleh pelaku tindakan, untuk meningkatkan kemantapan rasional dari tindakan-tindakan mereka dalam melaksanakan tugas, memperdalam pemahaman terhadap tindakan-tindakan yang dilakukan, serta memperbaiki dimana praktek-praktek pembelajaran dilaksanakan" (Karwono, 2008).

\section{Setting Penelitian}

Penelitian dilaksanakan di TK. Aisyiyah 6 Banjarmasin tahun ajaran 2013/2014 . penelitian ini merupakan penelitian tindakan kelas, dimana peneliti juga berperan sebagai guru pelaksana tindakan. Pelaksanaan penelitian adalah di kelompok B dengan 
jumlah anak sebanyaknya 18 anak yang terdiri 10 orang laki-laki dan 8 perempuan.

\section{Skenario Tindakan}

Penelitian tindakan kelas ini direncanakan terdiri dari dua siklus. Tiap siklus dilaksanakan dalam dua pertemuan. Tiap-tiap siklus direncanakan berkesinambungan, artinya proses dan hasil siklus 1 akan ditindak lanjuti dalam siklus 2. Prosedur penelitian tindakan kelas ini setiap siklus meliputi: (1) perencanaan (planing); (2) tindakan (acting); (3) observasi (observing); (4) evaluasi (evaluating); (5) refleksi (reflekting).

\section{Cara Penggalian Data}

Pengambilan data adalah data kemampuan anak yang diperoleh dari penilaian setiap pertemuan dan akhir tindakan. Anak berhasil berkembang sesuai harapan dengan mendapat $\geq 3$ bintang $(* * *)$.

Rumus

$$
\mathrm{N}=\frac{\text { jumlah perolehan bintang } \mathrm{x}}{\text { Jumlah aspek yang diamati }} 100
$$

\section{Hasil Penelitian}

\section{Siklus I Pertemuan 1}

\section{Hasil Observasi}

Adapun hasil pengembangan kognitif anak dalam mencocokkan bilangan dengan lambang bilangan sebagaimana pada tabel berikut :

Tabel Hasil Pengembangan Kognitif

\begin{tabular}{|l|l|l|}
\hline Nilai & \multicolumn{2}{|l|}{ Kognitif } \\
\hline & F & $\%$ \\
\hline & 5 & 27,78 \\
\hline \multirow{20}{*}{} & 5 & 27,78 \\
\hline Jumlah & 6 & 33,33 \\
\hline Berdasarkan tabel diatas data hasil
\end{tabular}

pengembangan/hasil belajar yang diperoleh pada aspek pengembangan kognitif yaitu hanya 5 orang anak yang berkembang sangat baik $(27,78 \%), 5$ orang anak berkembang sesuai harapan $(27,78 \%), 6$ orang anak mulai berkembanga $(33,33 \%)$ dan 2 orang anak belum berkembang $(11,11 \%)$ hal ini disebabkan karena anak masih kurang memahami bagaimana cara mengerjakan tugas tersebut dan anak keliru dalam menghubungkan lambang bilangan dengan gambar, akibatnya hasil pengembangan anak kurang optimal. Maka pada pertemuan berikutnya guru harus memperbaiki cara penyampaikan dalam mengerjakan tugas agar lebih dipahami anak.

\section{Refleksi Siklus I Pertemuan 1}

Hasil pengembangan yang diperoleh pada aspek pengembangan kognitif yaitu 6 orang anak mulai berkembang $(33,33 \%)$ dan 2 orang anak belum berkembang $(11,11 \%)$ hal ini disebabkan karena anak masih kurang memahami bagaimana cara mengerjakan tugas tersebut dan anak keliru dalam 
menghubungkan lambang bilangan dengan gambar. Maka pada pertemuan berikutnya guru harus memperbaiki cara penyampaikan dalam mengerjakan tugas agar lebih dipahami anak.

\section{Siklus I Pertemuan II}

\section{Hasil Observasi}

Hasil pengembangan kogntif dalam mencocokkan bilangan dengan lambang bilangan pada pertemuan kedua siklus I sebagaimana pada tabel berikut :

Tabel Hasil Pengembangan Kognitif Anak Pertemuan 2 Siklus 1

\begin{tabular}{|l|l|l|}
\hline Nilai & \multicolumn{2}{|l|}{ Kognitif } \\
\hline & F & $\%$ \\
\hline & 7 & 38,89 \\
\hline & 6 & 33,33 \\
\hline & 5 & 27,78 \\
\hline Jumlah & 0 & 0 \\
\hline
\end{tabular}

Berdasarkan tabel diatas data hasil pengembangan/hasil belajar yang diperoleh pada aspek pengembangan kognitif yaitu 7 orang anak berada pada katagori berkembang sangat baik $(38,89 \%), 6$ orang anak berkembang sesuai harapan $(33,33 \%)$ dan 5 orang anak mulai berkembang (27,78\%). Berikut adalah ketuntasan pengembangan kognitif secara klasikal pada siklus I pertemuan 2. Maka pada pertemuan berikutnya guru perlu lebih memberikan arahan dan bimbingan kepada anak sebelum mengerjakan tugas yang diberikan agar anak dapat memahami dan mudah dalam mengerjakan tugas tersebut.

\section{Refleksi Siklus I Pertemuan II}

Hasil pengembangan yang diperoleh pada aspek pengembangan kognitif yaitu 7 orang anak berada pada katagori berkembang sangat baik (38,89\%), 6 orang anak berkembang sesuai harapan $(33,33 \%)$ dan 5 orang anak mulai berkembang (27,78\%). Maka pada pertemuan berikutnya guru perlu lebih memberikan arahan dan bimbingan kepada anak sebelum mengerjakan tugas yang diberikan agar anak dapat memahami dan mudah dalam mengerjakan tugas tersebut.

\section{Refleksi Siklus I}

Hasil pengembangan kognitif pertemuan 1 siklus I masih belum memuaskan dan masih belum mencapai indicator ketuntasan yang ditetapkan peneliti yakni $80 \%$ anak mendapat bintang $3(* * *)$. Anak yang memperoleh bintang 4 hanya 5 orang dan yang memperoleh bintang 3 juga ada 5 orang anak. Hal ini disebabkan karena anak masih kurang memahami bagaimana cara mengerjakan tugas tersebut dan anak masih terlihat bingung. Demikian pula pengelolaan waktu yang kurang optimal sehingga anak menjadi terburu-buru dalam menjawab soal. Oleh karena itu, diperlukan sekali guru dalam 
membimbing dan mengarahkan siswa dalam mengerjakan tugas tersebut yang diberikan dengan pengelolaan waktu yang lebih baik lagi. Adapun hasil pengembangan anak pada pertemuan kedua mengalami peningkatan. Hal itu dapat dilihat bahwa ada 7 orang anak yang mendapat bintang 4 (****), 6 orang anak mendapat bintang 3 (***) dan 5 orang anak mendapatkan bintang $2(* *)$. Hasil tersebut masih belum memenuhi indicator keberhasilan yang ditetapkan. Maka pada pertemuan berikutnya guru harus memberikan bimbingan dan arahan yang lebih kepada anak sehingga anak dalam menjawab soal dapat diselesaikan dengan mudah serta waktu yang digunakan tidak terbuang percuma dan proses pembelajaran dapat berjalan lebih efektif lagi..Berdasarkan hasil tersebut diatas bahwa pada pertemuan 2 ini walaupun adanya peningkatan tetapi masih belum mencapai target yang ditetapkan peneliti $80 \%$ Sehingga perlu perbaikan pembelajaran pada pertemuan berikutnya dalam rangka meningkatkan pengembangan kognitif anak melalui model make a match.

Berdasarkan temuan-temuan ini menunjukkan bahwa perlu dilakukan kegiatan siklus II. Adapun tindakan-tindakan yang akan dilakukan peneliti pada siklus II adalah mengelola waktu lebih efektif dan efesien, menyampaikan model pembelajaran lebih terinci dan jelas serta menggunakan media yang lebih menarik dan variatif, memberikan bimbingan, arahan dan motivasi bagi siswa dalam belajar.

\section{Pelaksanaan Tindakan Kelas Siklus II}

\section{Hasil Observasi Pengembangan Kognitif}

Data hasil pengembangan kognitif anak dalam mencocokkan bilangan dengan lambang bilangan dapat dilihat pada table dibawah ini:

Tabel Hasil Pengembangan Kognitif Siklus

II

\begin{tabular}{|l|l|l|}
\hline Nilai & \multicolumn{2}{|l|}{ Kognitif } \\
\hline & F & $\%$ \\
\hline & 12 & 66,67 \\
\hline \multirow{2}{*}{} & 6 & 33,33 \\
\hline Jumlah & 0 & 0 \\
\hline & 0 & 0 \\
\hline
\end{tabular}

Berdasarkan tabel diatas data hasil pengembangan yang diperoleh pada aspek pengembangan kognitif yaitu 12 orang anak yang berkembang sangat baik $(66,67 \%)$ dan 6 orang anak yang berkembang sesuai harapan $(33,33 \%)$ hasil tersebut sudah memenuhi dari indicator keberhasilan yang ditetapkan yaitu lebih daro $80 \%$ anak mendapatkan bintang 3 .

\section{Refleksi Siklus II}

Hasil pengembangan kognitif pada pertemuan pertama pada siklus II ini mengalami peningkatan yang sangat memuaskan 
dibandingkan dengan pertemuan kedua siklus I. Secara individual ketuntasan hasil pengembangan dengan persentasi rata-rata $66,67 \%$ berkembang sangat baik dan $33,33 \%$ berkembang sesuai harapan. Peningkatan yang diperoleh pada siklus II pertemuan $1 \mathrm{ini}$ tidak terlepas dari dua hal yakni kegiatan pembelajaran dan aktivitas anak. Dari dua hal tersebut mengalami peningkatan sehingga hasil pengembanganpun juga meningkat. Kegiatan pembelajaran mengalami peningkatan karena adanya bimbingan arahan dan motivasi serta media yang digunakan lebih variatif sehingga anak lebih mudah dalam mengerjakan tugas yang diberikan. Disamping itupula peningkatan aktivitas anak disebabkan karena anak mulai terbiasa menggunakan model make a match dan motivasi yang diberikan guru sehingga pemahaman anak terhadap kegiatan yang dilakukan menjadi meningkat.

\section{E. Pembahasan}

Berdasarkan data yang diperoleh dari siklus I dan siklus II yang telah dilaksanakan dalam penelitian tindakan kelas yaitu tentang skenario kegiatan, pelaksanaan tindakan, hasil observasi dan refleksi, peneliti dapat memaparkan bahwa berdasarkan beberapa data dan temuan serta hasil refleksi bahwa rata-rata persentase hasil pengembangan kognitif anak siklus I pertemuan 1 sebesar $55,56 \%$ berkembang sesuai harapan dan
$44,44 \%$ mulai berkembang, pertemuan 2 sebesar $72,22 \%$ berkembang sesuai harapan dan $27,78 \%$ mulai berkembang sedangkan siklus II pertemuan 1 sebesar $100 \%$ anak sudah berkembang sesuai harapan.

Pengembangan kognitif adalah satu pengembangan kemampuan dasar anak, yang bertujuan agar anak mampu meningkatkan kemampuan dan kreativitas sesuai dengan tahap perkembangan. Di samping itu, anak dapat mengembangkan pengetahuan yang sudah diketahui dengan pengetahuan yang baru diperolehnya. Penggunaan model pembelajaran make a match yang tepat, yaitu dimulai dari aktivitas guru yang maksimal dalam menerapkannya dan juga adanya peningkatan aktivitas anak yang signifikan serta anak yang sudah tidak merasa bosan lagi dalam belajar akan memberikan dampak yang baik terhadap hasil pengembangan yang diperoleh anak.

Pengembangan berasal dari kata dasar kembang yang berarti menjadi bertambah sempurna. Kemudian mendapat imbuhan pean sehingga menjadi pengembangan yang artinya proses, cara atau perbuatan mengembangkan (Arisandi :2011,online). Jadi pengembangan disini adalah usaha sadar yang dilakukan untuk mencapai tujuan yang diinginkan agar lebih sempurna dari pada sebelumnya.

Kognitif adalah istilah yang digunakan oleh ahli psikologi untuk menjelaskan semua 
aktivitas mental yang berhubungan persepsi, pikiran, ingatan dan pengolahan informasi yang memungkinkan seseorang memperoleh pengetahuan, memecahkan masalah, dan merencanakan masa depan memperhatikan, mengamati, membayangkan, memperkirakan, menilai dan memikirkan lingkungannya.( Deswita, 2009)

Tujuan mengembangkan kecerdasan kognitif anak adalah mengembangkan berpikir anak untuk dapat mengolah perolehan belajarnya, dapat menemukan bermacam-macam alternative pemecahan masalah, membantu anak untuk mengembangkan kemampuan logika matematis dan pengetahuan akan ruang dan waktu, serta mempunyai kemampuan untuk memilah-milah, mengelompokkan, serta mempersiapkan kemampuan berpikir secara teliti.

Penggunaan model make a match anak akan mengalami langsung pembelajarannya,anak akan mendengarkan cara bermain , terlibat diskusi dalam penarikan kesimpulan dll. Penggunaan model make a match anak akan mengalami langsung pembelajarannya, anak akan mendengarkan cara bermain, terlibat diskusi dalam penarikan kesimpulan dan lainlain.

Slavin dalam Sanjaya (2009:242) mengemukakan dua alasan menggunakan pembelajaran kelompok. Pertama, beberapa hasil penelitian membuktikan bahwa penggunaan pembelajaran kooperatif dapat meningkatkan prestasi belajar siswa sekaligus dapat meningkatkan kemampuan hubungan sosial, menumbuhkan sikap menerima kekurangan diri dan orang lain, serta dapat meningkatkan harga diri. Kedua, pembelajaran kooperatif dapat merealisasikan kebutuhan siswa dalam belajar berpikir, memecahkan masalah, dan mengintegrasikan pengetahuan dengan keterampilan.

Dengan peningkatan hasil belajar tersebut berarti sesuai dengan tujuan dari pembelajaran kooperatif menurut Johnson \& Johnson dalam Trianto (2011:57) menyatakan bahwa tujuan pokok belajar kooperatif adalah memaksimalkan belajar siswa untuk peningkatan prestasi akademik dan pemahaman baik secara individu maupun secara kelompok. 


\section{DAFTAR PUSTAKA}

Arikunto, Suharsimi, dkk, 2006. Penelitian Tindakan Kelas. Jakarta : Bumi Aksara.

Arikunto, Suharsimi, 2009. Manajemen Penelitian. Jakarta : PT Rineka Cipta.

Asrori, dkk. (2009). Penelitian Tindakan Kelas. Yogyakarta: Multi Pressindo.

B.E.F. Montolalu,dkk, 2008. Bermain dan Permainan Anak, Jakarta: Universitas Terbuka Bungin. 2010. Metode Penulisan Karya Ilmiah. Jakarta: PT. Rineka Cipta

Hildayani Rini, dkk, 2005. Psikologi Perkembangan Anak, Jakarta: Universitas Terbuka Karwono. 2008. Penelitian Tindakan Kelas (Classroom Action Research). http://karwono.wordpress.com/2008/02/27/artikel-penelitian-tindakan-kelas-classroomaction-research/ (diakses 20 Desember 2013)

Masitoh,dkk, 2005. Strategi Pembelajaran TK. Jakarta

Moeslichatoen, 2004. Metode Pengajaran di Taman Kanak-Kanak. Jakarta : PT Rineka Cipta

Monks, F.C, dkk, 2001. Psikologi Perkembangan. Yogyakarta: Gadjah Mada University Press

Rahman, Hibana S. 2001. Konsep Dasar Pendidikan Anak Usia Dini. Yogyakarta: PGTKI Press

Sanjaya, Wina. (2009). Strategi Pembelajaran Berorientasi Standar Proses

Pendidikan. Jakarta: Kencana.

Semiawan, 2008. Belajar dan Pembelajaran Prasekolah dan Sekolah Dasar. Jakarta: PT. Macanan Cemerlang

Slameto, 2003. Belajar dan Faktor-Faktor yang Mempengaruhinya, Jakarta : Rineka Cipta

Slameto. (2010). Belajar \& Faktor-Faktor Yang Mempengaruhinya. Jakarta: Rineka Cipta.

Slamet Suyanto, 2005. Konsep Dasar Anak Usia Dini. Jakarta: Rineka Cipta

Suharsimi, 2009. Managemen Pendidikan. Jakarta : PT. Rineka Cipta

Suharsimi A, (2010). Penelitian Tindakan untuk Guru, Kepala Sekolah, dan Pengawas. Yogyakarta : Aditya Media

Sujiono, YN, et.al, (2005). Metode Pengembangan Kognitif. Jakarta : Pusat Penerbitan Universitas Terbuka.

Syah, Muhibbin. (2011). PSIKOLOGI PENDIDIKAN. Jakarta: Rajawali Pers.

Tim Instruktur PLPG Unlam, (2009). Modul Penelitian Tindakan Kelas. Banjarmasin:

Universitas Lambung Mangkurat 
Tim Penyusun, (2012). Pedoman Penulisan Skripsi Hasil Penelitian Tindakan Kelas (PTK).

Banjarmasin : FKIP Universitas Lambung Mangkurat

Tohirin. 2012. Metode Penelitian Kualitaif Dalam Pendidikan dan Bimbingan Konseling. Depok : PT Rajagrafindo Persada

Trianto. (2011). Mendesain Model Pembelajaran Inovatif-Progresif. Jakarta:

Kencana.

Winda Gunarti, dkk, 2008. Metode Pengembangan Perilaku dan Kemampuan Dasar Anak Usia Dini, Jakarta : Pusat Penerbitan Universitas Terbuka, edisi 3.

Wardhani, IGAK, et.al, (2002). Penelitian Tindakan Kelas (Modul). Jakarta : Pusat Penerbitan Universitas Terbuka. 